\title{
Partners in Parenting: An Overview of the Literature on Parents' and Nonparental Adults' Perspectives on Shared Responsibilities in Childrearing
}

\author{
Marije Kesselring (Corresponding Author) \\ Department of Education and Pedagogics, Utrecht University \\ PO Box 80140, 3508 TC Utrecht, the Netherlands \\ Email: m.c.kesselring@uu.nl \\ Micha de Winter \\ Department of Education and Pedagogics, Utrecht University \\ PO Box 80140, 3508 TC Utrecht, the Netherlands \\ Email: m.dewinter@uu.nl \\ Tom van Yperen \\ Department of Pedagogical and Educational Sciences, University of Groningen \\ PO Box 72, 9700 AB Groningen, the Netherlands \\ Email: t.a.van.yperen@rug.nl
}

Suzanne Lecluijze

Department of Education and Pedagogics, Utrecht University

PO Box 80140, 3508 TC Utrecht, the Netherlands

Email: suzannelecluijze@gmail.com

Received: December 21, 2015 Accepted: January 22, 2016 Published: June 11, 2016

doi:10.5296/iss.v4i1.8764

URL: http://dx.doi.org/10.5296/iss.v4i1.8764 


\section{Macrothink}

\section{Abstract}

The involvement of nonparental adults (NPAs) in the upbringing of children is widely considered to be important for the well-being of both children and parents. However, there has been no systematic overview of parental and nonparental perspectives toward this involvement. This study presents an overview of the international literature on sharing responsibility between parents and NPAs. A structured search resulted in the inclusion of 49 relevant publications. Limitations of the extant research notwithstanding, some generalizations about shared childrearing can be made. However, many issues relating the taboo of sharing childrearing responsibilities remain poorly understood. To break the taboo, future research should further explore the underlying sensitivities.

Keywords: literature overview, childrearing, shared responsibilities, parents, nonparental adults 


\section{Introduction}

Although parents are arguably the primary caregivers, bringing up children by definition takes place in a social environment consisting of several co-socialization agents such as family members, neighbors, sports coaches and teachers. The quality of the social environment appears to play a very important role in the development of problems such as child maltreatment and juvenile delinquency (De Winter, 2012; Garbarino \& Sherman, 1980). A study by Garbarino and Kostelny (1992) demonstrated that a stronger social fabric was associated with lower rates of child maltreatment, i.e., communities with lower rates of child maltreatment had strong informal and formal support networks, whereas communities with higher rates of child maltreatment were characterized by social disorganization and low levels of social cohesion. Despite empirical evidence for social and environmental effects on family functioning, scientific research as well as policy and practice appear to be dominated by the "at-risk model" according to which "dysfunction [...] is mainly seen as the outcome of individual risk factors and pathologies" (De Winter, 2012, p. 25). The risk assessment instruments and interventions that have been developed within this framework tend to focus on the micro-level of the family and on increasing professional efforts to identify and solve problems at an early stage. The dominance of the at-risk model may have hindered the development of other potentially effective approaches aimed at increasing families' well-being (De Winter, 2012).

The Dutch national program Allemaal Opvoeders (AlOp - Everybody a child-raiser), aims to broaden the narrow at-risk perspective by focusing on the role of civil society in the upbringing of children and adolescents. The program endorses the view that individual risk factors affect family functioning, but is also based on the hypothesis - supported by empirical evidence - that a strong social fabric is equally important (De Winter, 2012). The current study, which is part of the AlOp program, aimed to contribute to understanding of civil society's involvement in the upbringing of children and adolescents by providing an overview of the literature on shared childrearing responsibilities between parents and other caregivers, henceforward referred to as nonparental adults (NPAs).

\section{Nonparental Adults}

The literature consistently indicates that supportive NPAs can contribute to the well-being of both children and parents (e.g., Benson, Leffert, Scales, \& Blyth, 1998; Werner, 1993). The term NPAs refers to what these caregivers are not - parents - but does not in itself clarify which individuals may fulfill a supportive childrearing role. Some authors use other similar terms such as significant adults (Galbo, 1984), natural mentors (Rhodes, Ebert, \& Fischer, 1992) or VIPs (very important persons) (Greenberger, Chen, \& Beam, 1998). All of these terms are umbrella terms describing a wide range of supportive individuals (Sterrett, Jones, McKee, \& Kincaid, 2011), from members of the extended family to unrelated adults such as neighbors and teachers (Chen, Greenberger, Farruggia, Bush, \& Dong, 2003; Scales \& Gibbons, 1996). In this overview of the literature on shared responsibilities in the upbringing of children and adolescents we distinguish three categories of supportive NPAs, as shown in Figure 1. This distinction is based on the level of proximity (vertical axis) and degree of 
professionalism (horizontal axis).

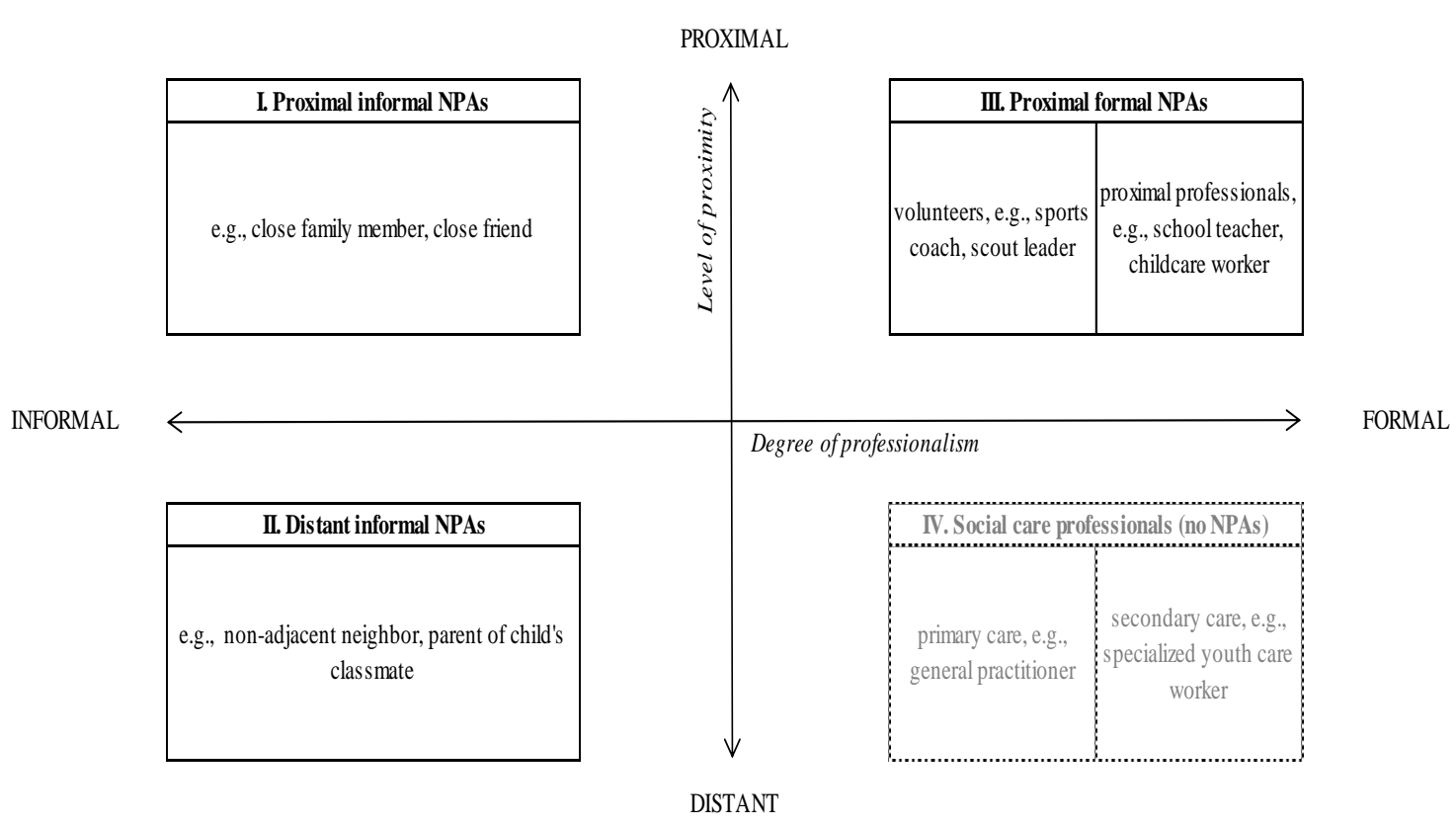

Figure 1. Schematic diagram of the three categories of supportive nonparental adults included in this study

The first category is the proximal informal NPAs. NPAs in this category are closely connected to the child and his or her parents through a nonprofessional bond, for example, grandparents and friends. The second category is the distant informal NPAs. NPAs in this category are nonprofessionals who are more loosely connected to the family than the proximal informal NPAs. Examples of NPAs in this second category are neighbors and the child's classmates' parents. NPAs in the third category - proximal formal NPAs - have some sort of formal status; they are connected to the family by virtue of their specific function or profession. This formal status can be both voluntarily, for example, scout leaders and sports coaches, and professional, for example, teachers and childcare workers.

Figure 1 also presents a fourth category of individuals: the social care professionals. We do not reckon these individuals among NPAs and this category falls outside the scope of this study. There is an important difference between the professionals in the third category and the professionals in the fourth category. Despite their formal status, professionals in the third category are naturally part of the family's social environment; because of their proximal relationships, all parents and children have frequent contact with professionals such as teachers and childcare workers (Raad voor Maatschappelijke Ontwikkeling (RMO) [Dutch Council for Social Development], 2012). Professionals in the fourth category, on the contrary, are not naturally part of the family's social environment and their relationship with families is more distant. Contact with these professionals may sometimes be necessary and may be an 
important source of support for a child and his or her parents, but - for most families - it is fair to say that contact with social care professionals is neither inevitable nor frequent (RMO, 2012).

The inclusion of (proximal) professionals in a study that is part of a program on enhancing civil society involvement in bringing up children may seem peculiar. Had we followed the common definition of civil society, we would have restricted our study to voluntary relationships, i.e., the division of responsibilities between parents and informal NPAs. However, we decided to include proximal professionals in this study, in order to provide a comprehensive overview of the literature on the willingness to share responsibilities in the upbringing of children and adolescents. The inclusion of proximal professionals was based on the assumption that they can fulfill an important supportive childrearing role, both directly, by taking the role of supportive NPAs themselves, and indirectly, by creating opportunities for parents to meet and exchange experiences with other parents and NPAs (Fisher \& Gruescu, 2011). It should be noted, however, that this implies that proximal professionals assume a role that extends beyond their primary professional responsibility. Teachers, for example, whose primary responsibility is to teach academic skills, may only be able to fulfill a direct and indirect supportive childrearing role when they consider themselves as true partners in nonacademic aspects of childrearing as well (RMO, 2012).

In summary, this study will focus on the international literature on parents' and NPAs' perspectives on sharing responsibilities for childrearing, using the following definition of NPAs: supportive related or unrelated individuals with informal or formal status who are naturally part of the family's social environment. Which individuals fall into each of the three categories of supportive NPAs, may differ from family to family. For example, for some families, neighbors may fulfill a more important supportive childrearing role than family members; in these families neighbors might fall into the first category, whereas family members might fall into the second category or might not even be part of the family's supportive network at all.

\section{This Study}

Despite the empirical evidence for the benefits of NPAs' involvement in childrearing, some literature suggests that it is taboo for parents and NPAs to share childrearing responsibilities (Scales et al., 2001, 2004). To date there has been no systematic overview of international evidence on the sensitivities underlying this taboo. Although a review by Scales and Gibbons (1996) provided insight into the differences between parental and nonparental childrearing roles, it did not explore parental and nonparental perspectives on childrearing roles. The current study aimed to improve understanding of parents' and NPAs' perspectives on shared childrearing by focusing on two objectives. First, we aimed to present an overview of the international literature on possible explanations for parents' and NPAs' perspectives toward shared childrearing. Second, we aimed to explore childrearing roles further by providing an analysis of the existing evidence on the division of childrearing responsibilities.

The topic of this study is closely linked to studies on parenting support. There has been considerable research in this field, for example, on (informal) parenting support as a 
protective factor, on availability of parenting support and on satisfaction with parenting support. However, it is important to note that the focus of this study was more specific. Rather than focusing on parenting support, we explored parents' and NPAs' attitudes to receiving and giving support in childrearing. This is relevant to the ongoing debate about enhancing civil society's involvement in bringing up children and the development of parenting support activities.

\section{Method}

\subsection{Search Procedure}

Four search strategies were used to identify relevant publications. First, a search of three electronic databases was performed: ERIC (Education Resources Information Center), PsycINFO and Scopus (subject area: Social Sciences \& Humanities). Second, the reference list from each publication already included in this study was examined to uncover other potentially relevant publications. Third, in an effort to identify relevant "gray literature" an Internet search was conducted. Finally, experts from youth institutes in Flanders (Flemish Center for Expertise on Parenting Support; EXPOO), Germany (Deutsches Jugendinstitut) and France (Institut National de la Jeunesse et de l'Éducation Populaire) were contacted by email to identify publications which might have been missed by the other search strategies (Petticrew \& Roberts, 2006).

Publications in English and Dutch from 1970 until September 2013 were eligible for inclusion in the study. A wide range of search terms was used, including: exclusive parenting, shared responsibility, childrearing ideology, significant adults, natural mentors, village, authoritative community, collective socialization and collaborative childrearing. Various types of publications were retrieved in the search procedure such as articles, reports, books, dissertations. We included both empirical and non-empirical publications. The latter type of publications are potentially an important source of insight into possible accounts of perspectives on shared childrearing, for example, explanations related to childrearing policy or to cultural aspects of childrearing ideology. For the same reason, we did not limit our search to publications on childrearing in Western societies, but also included relevant publications on childrearing in non-Western societies or on childrearing in migrant families living in Western countries.

\subsection{Selection Criteria}

Publications had to meet the following content criteria to be included in the study. First, publications had to be focused on possible explanations for parental and nonparental perspectives on shared childrearing or on the division of childrearing responsibilities between parents and NPAs. We excluded publications that focused only on the supportive role of NPAs in the upbringing of children without explicitly addressing factors related to shared childrearing responsibility. Second, publications had to include parent or NPA perspectives not just child or adolescent perspectives. 


\section{Results}

Our search of the three electronic databases yielded 60 potentially relevant publications. After further reading 39 of these publications were included in the study. Examination of the reference lists of these publications resulted in the inclusion of an additional 3 relevant publications. Our Internet search yielded another 7 publications and email communication with foreign youth institutes resulted in the identification of one potentially relevant book. We excluded this publication after scanning the table of contents and reading an online book review, because it did not meet the inclusion criteria. Altogether, 49 publications - 39 empirical and 10 non-empirical - were included in the current study (see Figure 2).

This results section is structured according to our two study objectives. First, we present existing research on possible explanations for parents' and NPAs' perspectives on shared childrearing. Second, we explore parental and nonparental roles in more detail by presenting what has already been written about the division of childrearing responsibilities. Table 1 (see Appendix I) provides a summary of the main characteristics of the publications included in the current study, presented in alphabetical order.

\section{Explanations for Parental and Non-parental Perspectives on Shared Childrearing}

The search resulted in the identification of 25 publications on possible explanations for parents' and NPAs' attitudes toward sharing childrearing responsibilities. We divided the explanatory factors mentioned in these publications into two categories: cultural explanations and contextual explanations.

\subsection{Cultural Explanations}

The publications within this category were divided into two subcategories: first, publications focused on explanations related to childrearing ideology in specific societies and regions and second, publications focused on the possible influence of cultural background.

\subsection{Childrearing Ideology}

A descriptive study by Van Daalen (2010) provided an historical overview of childrearing ideology in the Netherlands. Van Daalen suggested that although the male breadwinner model seems to have been at least partly replaced by a dual-earner model, the historic Dutch tradition of the nuclear family taking sole responsibility for childrearing may still be "anchored both in the institutions of the welfare state and in the mentality of the people" ( $p$. 351). This may have hindered the partial transfer of childrearing responsibilities to other caregivers (Van Daalen, 2010). Three publications by Scales and colleagues (2001, 2003, 2004) seem to be consistent with Van Daalen's conclusions. Like Van Daalen (2010), Scales and colleagues found that the Western ideology - in which the nuclear family is dominant discouraged people from sharing responsibilities. Although many American adults appear to believe that it is important to be involved in the upbringing of other people's children, "the social permission and expectation more commonly experienced in a true village" seem to be absent (Scales et al., 2001, p.711). Similarly, an older book chapter by McCartney and Phillips (1988) argued that Western childrearing ideology dominated childrearing practice. 


\section{Macrothink}

According to these authors the sensitivities surrounding shared childrearing are "a cultural byproduct that reflects and in turn promotes current American values" (p. 158).

A study by Feldman and Yirmiya (1986) demonstrated that the prevailing childrearing ideology may affect mothers' ideas on parental and nonparental roles and responsibilities. Their results showed that mothers in Israeli kibbutzim, where there is an ideology of shared childrearing, perceived NPAs to be as influential as mothers, although they believed in some role division. Mothers in kibbutzim believed their role was mainly nurturing and that the role of other caregivers was mainly didactic. Town-dwelling Israeli mothers, with an ideology of sole childrearing responsibility, believed that overall, mothers have more influence than NPAs (Feldman \& Yirmiya, 1986). A study by Maital and Bornstein (2003) drew similar conclusions. These authors suggested that the nurturer-teacher division may be characteristic not only of the childrearing ideology in kibbutzim, but of every setting where mothers and NPAs share childrearing responsibilities.

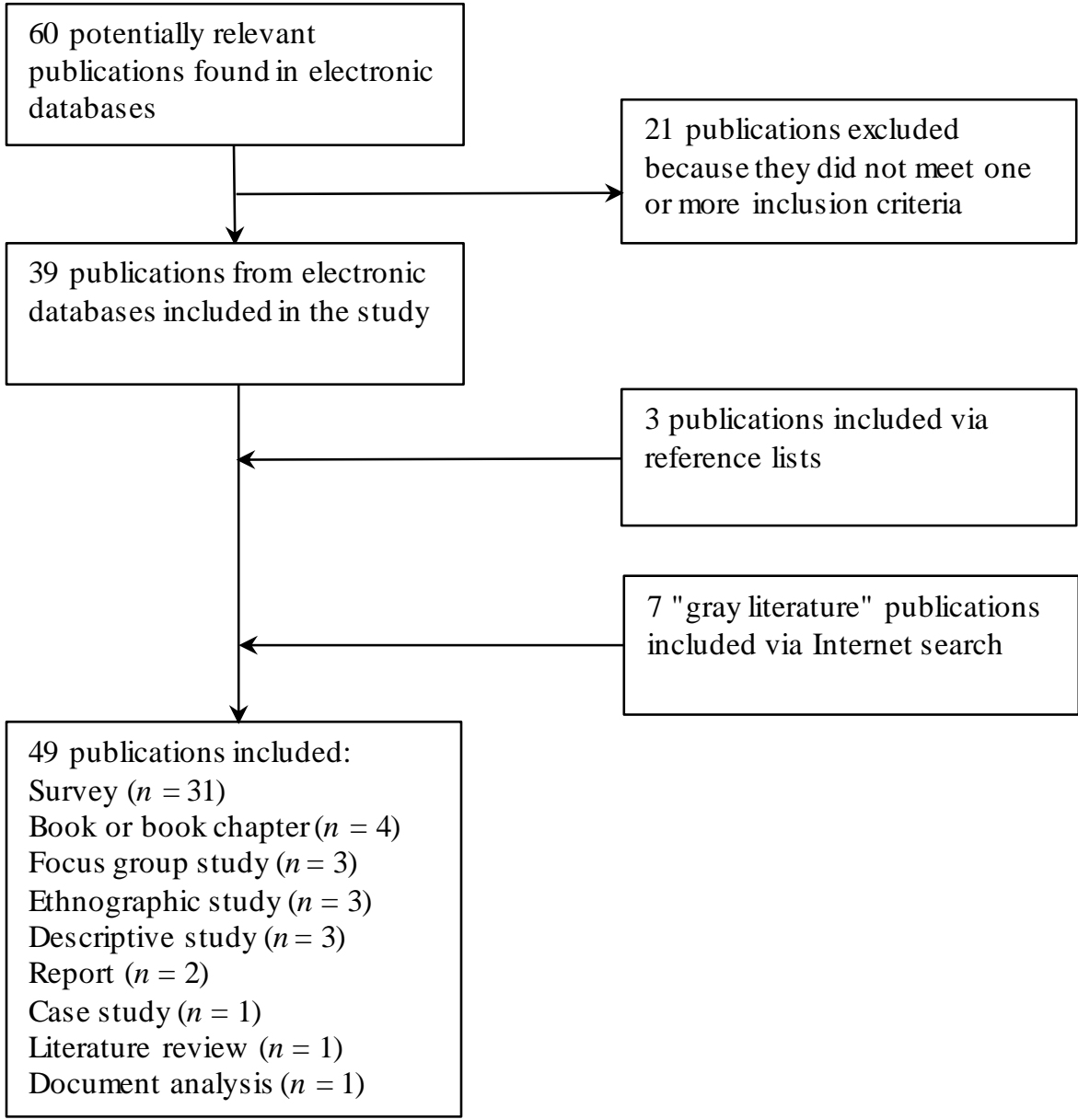

Figure 2. Flow chart for the structured literature search 


\section{Mll Macrothink}

Donner (1999) and Bowden Templeton and colleagues (2008) studied childrearing in societies with an ideology of shared childrearing. Donner (1999) studied the family system in a Polynesian society and compared it to the Western family system, showing that most Polynesian adults - both parents and nonparents - are involved in the upbringing of other people's children. Polynesian adults viewed the Western ideal of sole parental responsibility as a "lack [of] compassion" for other people's children (p. 703). According to the author, current Western policy - with its focus on the nuclear family - may be partly responsible for the maintenance of this ideal (see Policy influences). The author pleaded for a broader policy taking into account the influence of nonparental caregivers (Donner, 1999). Bowden Templeton and colleagues (2008) studied the childrearing ideas and practices of parents in the Appalachia, a U.S. region. All respondents - parents, adolescents and NPAs - believed that childrearing was a community responsibility and thought that all adults in the community could contribute to adolescents' well-being. These ideas seem to be put into practice; the interviews revealed that community members provided childrearing support for each other, for example, babysitting and transporting children. According to the respondents, "living in a small community" combined with "having known each other for such a long time" (p. 61) contributed to their beliefs and practices on collective childrearing responsibilities (Bowden Templeton, Bush, Lash, Robinson, \& Gale, 2008).

\subsection{Cultural Background}

As well as studies looking at childrearing ideology as a possible explanatory factor, other studies have explored whether parents' and NPAs' cultural background is associated with ideas about sharing childrearing responsibility. Gordon, Nichter and Henriksen (2013) conducted interviews with a small sample of black fathers $(N=7)$ living in the U.S. The fathers were positive about the idea that "it takes a village to raise a child", because most of them had benefited from childhood relationships with NPAs such as extended family members and the church. The fathers explained that NPAs provided them with "additional role models and a broader, more solid foundation" (p. 157).

A study of Caribbean immigrant families living in Britain showed that sharing responsibilities with extended family members was a reflection of cultural beliefs rather than economic necessity. Grandmothers, in particular, appeared to support their adult children by providing - mainly practical - childcare, mostly from a personal desire to be engaged in the upbringing of their grandchildren (Chamberlain, 2003). Another study focusing on immigrant perceptions of shared childrearing was conducted by Obeng (2007). This study demonstrated that although most African immigrant parents in the U.S. preferred informal over formal childcare, the majority took their children to a daycare center. The interviews revealed that parents perceived daycare centers - where multiple childcare workers took care of their child - as a form of childcare that corresponded to their tradition of shared childrearing (Obeng, 2007).

Cultural background as possible explanatory factor was also highlighted in a study of childcare arrangements in urban black and white American families which explored how parents shared specific childcare and parenting responsibilities (child management, setting 
rules, discipline, and providing children with emotional support). Both black and white families reported sharing these responsibilities with others, often with the other parent or stepparent or grandmother, but also with people outside the household. Black families were more likely to share responsibilities with extended family members and people from outside the household. It is important to note, however, that this result may be partly explained by differences in family structure as well. In this sample black caregivers were more likely than white caregivers to be single-parent families; the authors stated, "Black caregivers to some degree may be creating parenting systems that fill some of the gaps due to parental absence" (Hunter, Pearson, Ialongo, \& Kellam, 1998, p. 349). Another study of informal support networks for different groups of American parents showed that European Americans had more neighbors involved in practical support, whereas African Americans relied more heavily on family for practical support. There were no significant differences with respect to emotional support. According to the authors, these patterns of support may be related to cultural background, but also to social class and the availability of support, for example, how nearby the family's relatives live (Marshall, Noonan, McCartney, Marx, \& Keefe, 2001).

Kurrien and Vo (2004) studied the concept of coparenting in a sample of ethnic minority parents in the U.S., specifically parents with an Asian background. A study by Jones and colleagues (2007) focused on coparenting in a sample of parents with an African American background. The authors of both studies argued for a re-conceptualization of the concept of coparenting on the ground that a narrow definition of coparenting as the division of childrearing responsibilities between parents in intact or divorced families fails to account for the supportive role played by NPAs in immigrant families. According to Jones and colleagues (2007), it would be worthwhile to "broaden the definition of 'family' to include the other adults and family members who may be involved in parenting" (p. 679). This may increase recognition of the potential influences of NPAs on children raised in families with an immigrant background (Jones, Zalot, Foster, Sterrett, \& Chester, 2007; Kurrien \& Vo, 2004).

Finally, a study by Kakinuma (1993), which examined parenting magazines, revealed differences in the parenting attitudes of Japanese and American mothers. Japanese mothers appeared to use the magazines as a platform for exchange with other parents, whereas American mothers appeared to use the magazines as a source of information. More than half of the articles in Japanese magazines were based on mothers' input; the comparison figure for U.S. magazines was less than $10 \%$. According to the author, the differences in parental attitudes may "reflect differences in the childrearing traditions of both countries. Japanese childrearing is more communally oriented and sharing plays an important role. American childrearing, however, is a more private affair, where parents are responsible for gathering proper information" (Kakinuma, 1993, p. 235).

\subsection{Contextual Explanations}

Publications in this second category of possible explanations for parental and nonparental perspectives on shared childrearing responsibilities were divided into three subcategories: neighborhood characteristics, societal influences and policy influences. Two reports by the RMO (2008, 2009) focused on both societal and policy influences and will therefore be 
discussed in both subcategories.

\subsection{Neighborhood Characteristics}

Kegler and colleagues (2005) explored the link between U.S. parents' perceptions of neighborhood characteristics and various developmental assets, including the availability of an NPA role model. The results showed that neighborhood safety and informal social control were related to the existence of NPA role models. The authors explained this as follows: "if neighborhoods are perceived as safe, youth may spend more time outside the home and, as a result, have increased opportunities to form positive relationships with peer and nonparental adult role models" (p. 393).

A study by Burchinal and colleagues (2008) also pointed out the importance of neighborhood characteristics as a predictor of parents' willingness to share childrearing responsibilities. Their results demonstrated that in U.S. neighborhoods with higher sense of collective efficacy - where neighbors share values and trust each other - parents were more likely to choose day center care or informal childcare by non-relatives rather than relying exclusively on parental care or childcare by relatives (Burchinal, Nelson, Carlson, \& Brooks-Gunn, 2008).

Finally, Bould (2003) explored the existence of "caring neighborhoods" - neighborhoods with a sense of shared responsibility for childrearing - in the U.S. Neighborhoods were classified as caring if neighbors reported that they could talk about problems with the neighborhood youth, would know about child neglect or abuse, and would try to do something about this other than calling the police. The study revealed that caring neighborhoods do exist in modern suburbs. Three background factors appeared to be important for the development and maintenance of caring neighborhoods. First, in terms of socio-economic status and family structure caring neighborhoods appeared to be inhabited by white, middle-class, male-breadwinner families. Second, caring neighborhoods attached little value to privacy. Third, caring neighborhoods had high residential stability (Bould, 2003).

\subsection{Societal Influences}

Two reports by the RMO $(2008,2009)$ provided possible societal explanations for the diminishing of childrearing networks around nuclear families. Societal developments such as the disappearance of neighborhood facilities and greater distance between living and workplace environments have meant that nuclear families are less embedded in supportive social networks, and family and friends appear to have become less obvious co-socialization agents. According to the RMO, this may have contributed to Dutch parents' increased reliance on formal parenting support. Similar conclusions were drawn by Benson (2006) who concluded that societal developments such as age segregation and "the breakdown of trust" may be partly responsible for the gap between nonparental "belief and action" with respect to involvement with other people's children (p. 212).

Johnson Frankenberg, Holmqvist, and Rubenson (2013) also studied the influence of societal developments such as urbanization and globalization. Their study focused specifically on Tanzanian caregivers' - parents and grandparents - perspectives on shared childrearing responsibilities. Focus group discussions revealed that the ideal for childrearing seems to 
have shifted from communal responsibility to parents as primary caregivers. However, the results suggested that communal influences on children persist in environments where houses are built close together. The authors stated that although there appeared to be newly formed boundaries between parental and communal responsibilities, these seemed rather "fluid" ( $p$. 9), and that due to globalization and media influences members of a community may not share the same values, making collective childrearing "a delicate issue" (Johnson Frankenberg et al., 2013, p. 10).

\subsection{Policy Influences}

Two previously mentioned reports (RMO, 2008, 2009) described how Dutch national and local government policy may have contributed to the maintenance of the diminished childrearing networks around nuclear families. According to the RMO, governments try to fill the gap created by the declining capacity of the social environment. However, they may not be able to compensate for the loss of social embeddedness and the more they try to, the less NPAs and parents may actively try to share responsibilities (RMO, 2008, 2009).

A study by Kyriacou and colleagues (2013) provided insight into the possible influence of current Western education policy on teachers' ability and willingness to take a more active role in childrearing. The authors studied the perspective of English and Norwegian prospective teachers on the roles of parents, schools and other professional youth organizations in dealing with pupils' problems. The results revealed that prospective teachers thought that schools should take first responsibility for some areas of personal and social concern, namely bullying and pupil misbehavior. However, the authors also speculated about barriers to schools taking responsibility in more non-academic areas; in the current policy climate schools are expected to focus on pupils' development in literacy and numeracy skills and form partnerships with professional organizations to deal with pupils' problems. This overreliance on experts may discourage schools from taking a leading role in more areas of non-academic childrearing - or relieve them of responsibility in this area (Kyriacou, Avramidis, Stephens, \& Werler, 2013). Bakker and Van Oenen (2007) also discussed the impact of Western education policy and came to similar conclusions. Schools may be wary of broadening their non-academic functions, because they fear this might come at the expense of their core responsibility: pupils' development in literacy and numeracy skills (Bakker \& Van Oenen, 2007). In summary, an already crowded curriculum, combined with the current emphasis on literacy and numeracy skills and overdependence on (care) professionals might explain teachers' restraint in taking a more active role as secondary caregivers.

\section{Division of Childrearing Responsibilities between Parents and NPAs}

The search retrieved 24 publications on the division of childrearing responsibilities between parents and NPAs. A few of these publications were fairly general, but the majority focused on the division of responsibilities between parents and specific categories of informal or formal NPAs, for example, grandparents or teachers. Some of the publications explored the parent perspective, some the NPA perspective, and others looked at both parent and NPA perspectives. 
Shared responsibility between parents and NPAs

In a survey of 1090 Dutch parents, we found ambivalence about sharing responsibilities for childrearing (Kesselring, De Winter, Horjus, Van de Schoot, \& van Yperen, 2012). A majority of parents reported that they expected NPAs not to interfere in the upbringing of their children. On the other hand, a majority of parents also believed that NPAs can help out with childrearing. The results suggested that parents accept NPAs' involvement, but draw a line between "helping out" and "interfering". To explore the contradictions raised by the quantitative data, 100 parents were asked to explain their answers in more detail. These qualitative data revealed that most parents thought NPAs' main role should be correcting children's bad or dangerous behavior. We concluded that more research was needed to specify how parents draw the line between their own and other people's responsibilities. As we stated: "Through focus group interviews, we hope to gain a more detailed understanding of how parents define childrearing, which NPAs they perceive as significant partners in parenting, and how they expect these NPAs to support them" (Kesselring et al., 2012, p. 934).

Ambivalence about shared responsibility for childrearing was also evident in a study by Market Response (2010). Market Response was commissioned by the former Dutch Ministry for Youth and Family to conduct a survey on the attitudes of nearly 800 adult respondents parents and nonparents - toward civil society's involvement in childrearing. A majority of the respondents found it acceptable and desirable to reprimand or compliment other people's children. However, the respondents seemed reluctant to reprimand other people's children for fear of attracting a negative reaction from the parents or being thought to implicitly accusing the parents of negligence. Although a majority of the parents indicated that they would appreciate it if NPAs were to reprimand their children, they believed "actual childrearing tasks" (not further specified) were parents' responsibility. In addition, most parents indicated that although they appreciate it, they do not expect NPAs to take an active role in bringing up their children. Respondents' reflections on vignettes suggested that both parents and nonparents took their role in bringing up other people's children seriously. Almost all respondents reported that they would correct children's dangerous or annoying behavior. However, there were situations, for example, a neighbor child seemed to be unhappy or was bullied by other neighborhood children, where the majority of the respondents said they would not step in. The results also showed that respondents believed it was important to be a good role model, for example, wait until the traffic lights have changed to green. In summary, the results of the Market Response study were consistent with our study (Kesselring et al., 2012), suggesting that the involvement of NPAs is thought desirable, but comes with conditions.

Conditions in which shared childrearing was acceptable and desirable were also found in a study by Uttal (1996), who interviewed employed U.S. mothers about the meaning of childcare, provided by informal babysitters such as relatives, or professionals such as daycare workers. In interviews mothers talked about "what they expect their childcare providers to do for their children and what they defined as the boundaries of that care" (p. 298). Three different ways of viewing childcare were identified from the interviews: as custodial care, surrogate care or coordinated care. Mothers who took a custodial care perspective saw 
themselves as primary socialization agents and believed childcare providers' role should be limited to supervising their children and meeting their direct physical and emotional needs. These mothers (9 out of 31) thought that childcare providers did not have a role as substitute parents and should only have limited influence on the social and moral development of their children. Mothers who viewed childcare as custodial wanted to stay in control, even if they were at work, for example, by giving instructions by telephone. Only a few mothers (3 out of 31) believed childcare to be surrogate care. These mothers saw their child's caregivers as primary caregivers and thought of childcare and childrearing as similar activities, or - more emphatically - felt that childcare could be a substitute for mothering. A majority of the mothers (19 out of 31) adhered to the coordinated care view. These mothers felt that responsibility for childrearing was shared between them and their child's caregivers. These mothers perceived childcare "as an extension of home, and vice versa" (p. 305); good communication with childcare providers and shared childrearing philosophy, values and practice appeared to be especially important to them (Uttal, 1996). In summary, in line with our own study and the Market Response study, Uttal's study showed that mothers tend to view childrearing as a shared responsibility, but most of them set conditions, for example, with respect to communication and agreed practice. It is important to note that the three views that emerged from the interviews do not necessarily represent mothers' preferred division of childcare responsibilities, rather they correspond to their understanding of how they share responsibility for childrearing in practice (Uttal, 1996).

Edwards and Gillies (2004) studied U.K. parents' norms about sources of various types of parenting support. They found that although parents may have been receiving less informal support than in the past (for various reasons, for example, families are less close-knit nowadays, divorce is more prevalent, and extended families are more geographically dispersed), parents nevertheless identified relatives and friends as the main source of emotional support and advice on children's behavior. In addition, there appeared to be consensus amongst the respondents that relatives were the most appropriate source of practical support. The parents seemed to regard professionals as secondary or additional source of practical support and advice on health and education (Edwards \& Gillies, 2004). Although this study did not focus directly on parents' attitudes toward sharing responsibilities, it demonstrated that parents rely on informal and formal NPAs for different types of support. In a qualitative follow-up study by Gillies (2004), a majority of the parents interviewed indicated they were both recipients and providers of parenting support from and to family, friends and neighbors. This reciprocal support tended to be mainly practical, for example, picking up children from school. In line with the results of the earlier quantitative study, parents were most likely to turn to family and close friends for emotional support. Although emotional support was much appreciated, "advice was more generally mistrusted and associated with interference" (p. 255). This may have been especially true of formal advice as many parents indicated that "they had gained useful tips through sharing experiences with other parents" (p. 256).

\subsection{Childrearing roles and responsibilities of specific groups of NPAs}

\subsubsection{Grandparents}


Mason, May and Clarke (2007) studied the meaning of contemporary grandparenthood from the perspective of grandparents in the U.K. Like some of the studies discussed above, this study found evidence of ambivalence. There was high degree of consensus amongst the respondents about the importance of two contradictory norms: "not interfering" and "being there" (p. 701). Grandparents mentioned two reasons for the importance of the no interference norm. First, they believed that it was not good for children to have their grandparents openly question their parents' authority or provide inconsistent messages. Second, grandparents stated that they associated interference with bad parenting of their adult children; they felt that a good parent should allow his or her adult children to choose their own life, implying a freedom "to bring up their own children in their own way" (p. 691). However in practice, recognition of their adult children's parental authority was sometimes in conflict with the other norm of good grandparenting, "being there", which seemed to be strongly related to love, interest and a feeling of responsibility for grandchildren. The results suggested that grandparents were constantly trying to find a balance between the two norms; they tried to refrain from interfering too much whilst at the same time trying to be a constant, supportive presence (Mason et al., 2007).

Budini Gattai and Musatti (1999) also wrote about grandparental involvement in childcare. The study, based on a sample of 30 Italian grandmothers, reported that grandmothers believed that parents had final responsibility for their children's upbringing. Grandmothers seemed to play the role of substitute parents if the parents were absent, but as soon as the parents returned, grandmothers "can return to a purely affective relationship" (p. 38). Some grandmothers described their role as "being left with the more enjoyable part" of childrearing (p. 38). Although most grandmothers saw their limited responsibility - compared to the experience of being a mother - as a relief, this role division may put them in a vulnerable position, because parents may decide to delegate their authority to the grandmothers temporarily, but they may also withdraw it. Some grandmothers indicated that this makes them hesitant to discuss their doubts and feelings about their children's methods and style of childrearing. Nevertheless, some grandmothers reported conflicts with their adult children about the upbringing of their grandchildren, for example, some adult children were frustrated with the grandmother's indulgent attitude toward the grandchildren, whereas some grandmothers were ambivalent about the greater familiarity between parents and children in contemporary society (Budini Gattai \& Musatti, 1999).

\subsubsection{Mentors}

Spencer and colleagues (2011) studied parents' hopes and expectations of formally organized youth-mentor relationships. The study, based on a small ethnically diverse sample $(N=13)$ of American parents, showed that parents wanted mentors to be positive role models and confidants for their children. They also wanted mentors to provide children with experiences and opportunities different from those they and other NPAs in the child's network could offer. Parents thought it was important that mentors respected their parental guidelines. This seems to contribute to parental trust in the mentor relationship (Spencer, Basualdo-Delmonico, \& Lewis, 2011). On the basis of this study, we may tentatively conclude that parents appreciate specific aspects of the mentor's role that are mainly seen as additional to the parent's role. 


\subsubsection{Playground Workers}

Konijn (2008) studied Dutch playground workers' opinions about the function of playgrounds in preventing problems in children and young people. The results suggested that playground workers shy away from questions about the preventive role of playground activities. Respondents indicated that they saw the playground as a safe place for all children to play, and as a meeting place, not as a place for education or as an important place to signalize problems (Konijn, 2008). It appears that playground workers did not feel they had a direct role in childrearing, but they were perhaps comfortable fulfilling an indirect role by creating the conditions in which parents and NPAs can meet.

\subsubsection{Teachers}

Most of the publications on the division of responsibilities between parents and teachers focused on shared responsibility with respect to a specific childrearing topic, for example, health education, but some focused on shared parent-teacher responsibility in general. An example of the latter is the study by Lindle and Boyd (1991) of childrearing partnerships between U.S. parents and teachers. This study demonstrated that parents "were not willing to relinquish responsibility, but rather were interested in support from the school in meeting those responsibilities" (p. 335). One way schools could provide this support is by organizing social activities that give parents the opportunity to meet other parents, for example, a parent support group where parents can discuss childrearing issues. This study also revealed that parents were "ambivalent about the complementariness" of the childrearing roles of parents and teachers (p. 334). Parents wanted to be supported in their parenting role, yet they experienced some of the teachers' childrearing actions as an intrusion on their parental territory, for example, a teacher disciplining a child without informing the parents. This study showed that teachers faced a challenge: to support parents without encroaching their territory (Lindle \& Boyd, 1991). Another study of parent-teacher partnerships in the U.S. - although it was based on a small sample - showed that both parents and teachers believed teachers to be the "education and child development experts" and expected them to take the advice givers role (Cheatham \& Otrosky, 2011, p. 29). Parents mostly took the role of advice recipients and parent-to-teacher advice was rare. The authors concluded that due to this hierarchy, parents' expertise remained unrecognized. Forsberg (2007) also reported on the expert roles of parents and teachers, but in contrast to the study by Cheatham and Otrosky (2011), Forsberg argued that the division of responsibilities is "negotiated in terms of expertise" (p. 286). From interviews with Swedish parents and analysis of correspondence (school letters) between school and caregivers, Forsberg concluded that in educational matters both parents and teachers saw teachers as the experts, but when it came to childrearing issues, including children's behavior in school, the roles changed and parents were recognized as the experts. This nurturer-teacher division is somewhat similar to the pattern described by Maital and Bornstein (2003) in their study of shared childrearing in kibbutzim.

Åman-Back and Björkqvist (2007) studied Finnish parents' and teachers’ perspectives on shared responsibility for a variety of skills. Both parents and teachers indicated that they shared responsibility for teaching socio-emotional skills (e.g., conflict resolution and sense of 
justice) and for sexual health education and drug education. Fathers were more likely than mothers to agree that teachers had greater responsibility in these domains. A study of a sample of Swedish parents had a more specific focus: parental perspectives on parents' and teachers' roles in various aspects of health education. Parents considered some health topics to be solely or mainly their responsibility (e.g., appropriate clothing, and adequate sleep and rest), but other topics were regarded as a joint responsibility, shared between parents and schools (e.g., bullying and tobacco use). Parents from rural areas and younger parents were more likely to think that responsibility for a health education issue should be shared equally between parents and teachers (Sormunen, Tossavainen, \& Turunen, 2012). One Canadian and two Australian studies dealt specifically with sexual health education. The results of these studies suggested that parents believed that responsibility for sexual health education was shared between parents and teachers; nonetheless, parents appeared to see themselves primarily responsible and thought the teacher's role was supplementary. Parents expected teachers to inform them about the curriculum, to involve them and to provide them with information about communication strategies they could use in sexual education at home (Berne et al., 2000; Dyson \& Smith, 2012; Weaver, Byers, Sears, Cohen, \& Randall, 2002).

A study by Wyman, Price, Jordan, Dake, and Telljohann (2006) demonstrated that U.S. parents thought another health-related topic, smoking prevention, was also a joint responsibility of parents and teachers. Again, parents wanted to be involved and informed. In contrast to Åman-Back and Björkqvist's (2007) findings, mothers were more likely than fathers to agree that teachers should have a role in the prevention of smoking.

Finally, an Irish study on discussing death and grief with children, showed that parents were positive about programs discussing death and grief in schools. A majority of the teachers $(62 \%)$ and half the parents thought that discussing death and grief was best done by parents; a minority of both respondent groups thought that work by teachers on this topic could potentially interfere with parental responsibility (McGovern \& Berry, 2000).

\subsubsection{Childcare Workers}

A descriptive study by Verzaro-Lawrence (1981) shed light on potential stressors in the relationship between mothers and childcare workers such as parental anxiety about childcare workers' judgment of their parenting skills. As a more recent study by Fothergill (2013) confirmed, mothers seem to struggle with feelings of anxiety. In addition, Fothergill's study showed that mothers' feelings about childcare centers may be influenced by messages about formal childcare such as relatives', friends' and media (dis)approval of abdicating of parental responsibilities. Furthermore, Fothergill showed that the "intensive mothering" (p. 25) ideology, which holds that the best childcare is provided by mothers, seems to influence mothers' feelings about formal childcare. To comply with this ideology, mothers appeared to spend a great amount of time and effort, including calling references, on finding a good quality daycare center for their child (Fothergill, 2013).

Singer (1992) studied Dutch parents' perspectives on their relationships with childcare workers. Parents reported that it was very important to build a relationship of mutual trust with childcare workers. Most parents in the study never received feedback from childcare 
workers, although they gave feedback to childcare workers. A possible explanation for this is that parents are regarded as primary caregivers who are only delegating a part of their responsibility to childcare workers. Parents may feel that their parental responsibility includes making sure that childcare workers take good care of their children (Singer, 1992).

In a study of Hungarian parents' perspectives on what children should learn at home and in daycare centers, parents indicated that parents and childcare workers had different responsibilities. Parents perceived both roles "as different, but complementary" (p. 277). Parents believed it was their responsibility to teach their children good manners and other values, but that cognitive and social skills should be learned in daycare centers (Brayfield \& Korintus, 2011).

\section{Discussion}

To the best of our knowledge, this study is the first to present an overview of the international literature on parents' and NPAs' willingness to share responsibility for the upbringing of children. This study had two objectives. First, presenting existing explanatory accounts of parental and nonparental attitudes to shared childrearing. Second, exploring the childrearing roles of parents and NPAs by analyzing existing literature on the division of responsibilities. Forty-nine relevant publications were identified in a structured search of the international literature. However, methodological problems limit the strength of our conclusions. Nearly half the empirical studies included in this study were based on a small sample (see Table 1). In addition, use of different data gathering methods affects the comparability of the empirical studies included.

Our study has highlighted some limitations of the existing research. A considerable number of studies focused on "proximal formal NPAs" (third category in Figure 1), especially on teachers (see Table 1). Only a relatively small number of studies investigated the role of informal NPAs, particularly the NPAs we classified as "informal distant" (second category in Figure 1) such as neighbors and parents of the child's classmates. Future research should investigate the role of this category of NPAs because it is at the heart of civil society. These NPAs are not connected to parents and children by familial or other close ties, or by a specific role or function. On the contrary, the involvement of this group of informal distant NPAs reflects the voluntary associations that are so characteristic of civil society. Programs that aim to enhance civil society's involvement in bringing up children will only take root if we gain a better understanding of the roles and responsibilities assumed by "ordinary citizens".

Despite the methodological weaknesses and limitations of the existing research, some generalizations about shared childrearing can be made. Some of the publications relevant to our first study objective suggested that the sensitivities surrounding shared childrearing in Western societies may stem from the prevailing cultural ideology (McCartney \& Phillips, 1988; Scales et al., 2001, 2003, 2004; Van Daalen, 2010). In Western societies there appears to be a historical tradition that childrearing is solely the responsibility of the nuclear family; this tradition may be embedded not only in the mentality of citizens - parents and nonparents - but also in youth and family policy. Nevertheless, the concept of shared responsibility is 
definitely acknowledged. However, the concept of shared responsibility seems mainly to be reflected in people's beliefs rather than their actions (Scales et al., 2001, 2004). Encouraging public debate - amongst parents and NPAs, and policy makers and professionals - on norms and expectations related to shared childrearing might help to align beliefs and actions. Such a debate may contribute to our understanding of factors hindering the partial transfer of parental childrearing responsibilities to NPAs and to the breakdown of barriers to shared childrearing.

Although limited in scope, the data presented here indicated that some neighborhood characteristics may be related to citizens' willingness to commit themselves to being part of the neighborhood children's lives (Bould, 2003; Burchinal et al., 2008; Kegler et al., 2005). It appears to be important that neighbors have some sense of collective efficacy for children, i.e., "shared expectations and mutual engagement by adults in the active support and social control of children" (Sampson, Morenoff, \& Earls, 1999, p. 635). Neighborhood activities may help to foster a neighborhood climate favorable to developing collective efficacy for children (Kesselring, De Winter, Horjus, \& Van Yperen, 2013). If neighbors participate in collective activities, they get to know each other better. It is conceivable that this increase in public familiarity (Blokland, 2008) lowers the threshold for keeping an eye on each other's children and speaking out about expectations. Proximal professionals can play a role in organizing neighborhood activities, for example, by making a room in a school or Centrum voor Jeugd en Gezin (CJG - Youth and Family Center) available for people to meet as a group. In line with the findings of Lindle and Boyd (1991), this type of facilitative activity may provide parents with childrearing support without requiring that they relinquish their parental responsibility. As described in the introduction of this chapter, proximal professionals' willingness to fulfill a supportive childrearing role - whether direct or indirect - is linked to their perception of their role (RMO, 2012). For some, an adjustment to the way they think about their role may be required. However, proximal professionals may only be able to make this adjustment if governments and managers of professional organizations give them license to assume a role in childrearing that goes beyond their primary responsibilities.

Our second study objective was to explore parental and nonparental roles in childrearing by focusing on research into the division of childrearing responsibilities. This is clearly a sensitive issue; nevertheless multiple studies have demonstrated that both parents and NPAs are willing to share responsibilities. Parents and NPAs appear to believe that sharing responsibility can be worthwhile. NPAs seem to take their role as secondary caregivers seriously; they also seem to be aware of the danger of seeming to intrude. For parents staying in control appears to be important. Parents place great importance on communication and shared values and practice in childrearing; they expect NPAs to inform and involve them in their childrearing actions. Furthermore, some of the studies provided evidence for the existence of separate "territories of responsibility", for example, teachers may be the experts in the educational domain whilst parents are the experts in the childrearing domain.

Some limitations of this study must be acknowledged. Our search in the electronic databases may not have identified all relevant publications for various reasons. First, our search was limited to publications written in English or Dutch. Second, given the breadth of our study we 
cannot guarantee that all relevant publications were identified, although we used a wide range of search terms. However, by using additional search strategies - examination of reference lists, a "gray literature" search and email communication with experts in international youth institutes - we may have compensated for these potential problems with the search of the electronic databases. Notwithstanding these limitations, this study has provided insight into parental and nonparental perspectives on shared childrearing and on the division of roles between parents and NPAs. However, many aspects of the taboo on sharing childrearing responsibilities remain poorly understood. To break this taboo, future research is needed to improve understanding of the underlying sensitivities.

\section{References}

Åman-Back, S., \& Björkqvist, K. (2007). Parents' and teachers' attitudes regarding school involvement in education that extends beyond the traditional academic core. Perceptual and Motor Skills, 104, 1017-1024. http://dx.doi.org/10.2466/pms.104.3.1017-1024

Bakker, K., \& Van Oenen, S. (2007). Vernieuwing van de pedagogische infrastructuur voor 0-12 jarigen [Renewal of the pedagogical infrastructure for 0-12 year olds]. In P. A. H. van Lieshout, M. S. S. van der Meij., \& J. C. I. De Pree (Eds.), Bouwstenen voor betrokken jeugdbeleid [Building blocks for involved youth policy] (pp. 183-198). Amsterdam, the Netherlands: Amsterdam University Press.

Benson, P. L., Leffert, N., Scales, P. C., \& Blyth, D. A. (1998). Beyond the 'village' rhetoric: Creating healthy communities for children and adolescents. Applied Developmental Science, 2(3), 138-159. http://dx.doi.org/10.1207/s1532480xads0203_3

Benson, P. L. (2006). All kids are our kids: What communities must do to raise caring and responsible children and adolescents (2nd ed.). San Francisco, CA: Jossey-Bass.

Berne, L. A., Patton, W., Milton, J., Hunt, L. Y. A., Wright, S., Peppard, J., \& Dodd, J. (2000). A qualitative assessment of Australian parents' perceptions of sexuality education and communication. Journal of Sex Education and Therapy, 25(2/ 3), 161-168.

Blokland, T. (2008). Ontmoeten doet ertoe [Meeting matters]. Rotterdam, the Netherlands: Vestia.

Bould, S. (2003). Caring neighborhoods: Bringing up the kids together. Journal of Family Issues, 24(4), 427-447. http://dx.doi.org/10.1177/0192513X02250830

Bowden Templeton, G., Bush, K. R., Lash, S. B., Robinson, V., \& Gale, J. (2008). Adolescent socialization in rural Appalachia: The perspectives of teens, parents, and significant adults. Marriage and Family Review, 44(1), 52-80. http://dx.doi.org/10.1080/01494920802185322

Brayfield, A., \& Korintus, M. (2011). Early childhood socialization: Societal context and childrearing values in Hungary. Journal of Early Childhood Research, 9(3), 262-279. http://dx.doi.org/10.1177/1476718X11402444 
Budini Gattai, F., \& Musatti, T. (1999). Grandmothers' involvement in grandchildren's care: Attitudes, feelings, and emotions. Family Relations, 48(1), 35-42. http://dx.doi.org/10.2307/585680

Burchinal, M., Nelson, L., Carlson, M., \& Brooks-Gunn, J. (2008). Neighborhood characteristics and child care type and quality. Early Education and Development, 19(5), 702-725. http://dx.doi.org/10.1080/10409280802375273

Chamberlain, M. (2003). Rethinking Caribbean families: Extending the links. Community, Work \& Family, 6(1), 63-76. http://dx.doi.org/10.1080/1366880032000063905

Cheatham, G. A., \& Otrosky, M. M. (2011). Whose expertise?: An analysis of advice giving in early childhood parent-teacher conferences. Journal of Research in Childhood Education, 25, 24-44. http://dx.doi.org/10.1080/02568543.2011.533116

Chen, C., Greenberger, E., Farruggia, S., Bush, K., \& Dong, Q. (2003). Beyond parents and peers: The role of important non-parental adults (VIPs) in adolescent development in China and The United States. Psychology in the Schools, 40(1), 35-50. http://dx.doi.org/10.1002/pits.10068

De Winter, M. (2012). Socialization and Civil Society. How parents, teachers and others could foster a democratic way of life. Rotterdam/ Boston/ Taipei: Sense Publishers.

Donner, W. W. (1999). Sharing and compassion: Fosterage in a Polynesian society. Journal of Comparative Family Studies, 30, 703-722.

Dyson, S., \& Smith, E. (2012). 'There are lots of different kinds of normal': Families and sex education - styles, approaches and concerns. Sex Education: Sexuality, Society and Learning, 12(2) 219-229.

Edwards, R., \& Gillies, V. (2004). Support in parenting: Values and consensus concerning who to turn to. Journal of Social Policy, 33(4), 627-647. http://dx.doi.org/10.1017/S0047279404008037

Feldman, S., \& Yirmiya, N. (1986). Perception of socialization roles: A study of Israeli mothers in town and kibbutz. International Journal of Psychology, 21, 153-165. http://dx.doi.org/10.1080/00207598608247581

Fisher, D., \& Gruescu, S. (2011). Children and the Big Society. Backing communities to keep the next generation safe and happy. London, UK: ResPublica.

Forsberg, L. (2007). Involving parents through school letters: Mothers, fathers and teachers negotiating children's education and rearing. Ethnography and Education, 2(3), 273-288. http://dx.doi.org/10.1080/17457820701547252

Fothergill, A. (2013). Managing childcare: The experiences of mothers and childcare workers. Sociological Inquiry, 83(3), 421-447. http://dx.doi.org/10.1111/soin.12011

Galbo, J. J. (1984). Adolescents' perceptions of significant adults: A review of the literature. Adolescence, 19(76), 951-970. 


\section{Mll Macrothink}

Garbarino, J., \& Sherman, D. (1980). High-risk neighborhoods and high-risk families: The human ecology of child maltreatment. Child Development, 51, 188-198. http://dx.doi.org/10.2307/1129606

Garbarino, J., \& Kostelny, K. (1992). Child maltreatment as community problem. Child Abuse \& Neglect, 16, 455-464. http://dx.doi.org/10.1016/0145-2134(92)90062-V

Gillies, V. (2005). Parenting and social capital: Accessing help and support from informal social networks. Sociologija, 46(3), 245-258. http://dx.doi.org/10.2298/SOC0403245G

Gordon, T. V., Nichter, M., \& Henriksen, R. C. (2013). Raising Black males from a Black father's perspective: A phenomenological study. The Family Journal: Counseling and Therapy for Couples and Families, 21(2), 154-161. http://dx.doi.org/10.1177/1066480712466541

Greenberger, E., Chen, C., \& Beam. M. R. (1998). The role of "Very Important" Nonparental Adults in adolescent development. Journal of Youth and Adolescence, 27(3), 321-343. http://dx.doi.org/10.1023/A:1022803120166

Hunter, A. G., Pearson, J. L., Ialongo, N. S., \& Kellam, S. G. (1998). Parenting alone to multiple caregivers: Child care and parenting arrangements in Black and White urban families. Family Relations, 47(4), 343-353. http://dx.doi.org/10.2307/585265

Johnson Frankenberg, S., Holmqvist, R., \& Rubenson, B. (2013). "In earlier days everyone could discipline children, now they have rights": Caregiving dilemmas of guidance and control in urban Tanzania. Journal of Community \& Applied Social Psychology, Published online in Wiley Online Library. http://onlinelibrary.wiley.com/doi/10.1002/casp.2160/abstract

Jones, D. J., Zalot, A. A., Foster, S. E., Sterrett, E., \& Chester, C. (2007). A review of childrearing in African American single mother families: The relevance of a coparenting framework. Journal of Child and Family Studies, 16, 671-683. http://dx.doi.org/10.1007 /s10826-006-9115-0

Kakinuma, M. (1993). A comparison of child rearing attitudes of Japanese and American mothers. Childhood: A Global Journal of Child Research, 1, 235-242. http://dx.doi.org /10.1177/090756829300100406

Kegler, M. C., Oma, R. F., Vesely, S. K., McLeroy, K. R., Aspy, C. B., Rodine, S., \& Marshall, L. (2005). Relationships among youth assets and neighborhood and community resources. Health, Education and Behavior, 32(3), 380-397. http://dx.doi.org/10.1177 /1090198104272334

Kesselring, M., De Winter, M., Horjus. B, Van de Schoot, R., \& Van Yperen, T. (2012). Do parents think it takes a village? Parents' attitudes towards nonparental adults' involvement in the upbringing and nurture of children. Journal of Community Psychology, 40(8), 921-937. http://dx.doi.org/10.1002/jcop.21497 


\section{Macrothink}

Kesselring, M., De Winter, M., Horjus, B., \& Van Yperen, T. (2013). Allemaal Opvoeders in de pedagogische civil society. Naar een theoretisch raamwerk van een ander paradigma voor opgroeien en opvoeden [Everybody a child-raiser in the educative civil society. Toward a theoretical framework of an alternative paradigm to the upbringing of children]. Pedagogiek, 33(1), 5-20.

Konijn, H. (2008). Over de preventieve buurtfunctie van speeltuinen [About the preventive neighborhood-function of playgrounds]. Rotterdam, the Netherlands: PJ Partners.

Kurrien, R., \& Vo, E. D. (2004). Who's in Charge?: Coparenting in South and Southeast Asian Families. Journal of Adult Development, 11(3), 207-219. http://dx.doi.org /10.1023/B:JADE.0000035628.42529.e5

Kyriacou, C., Avramidis, E., Stephens, P., \& Werler, T. (2013). Social pedagogy in schools: Student teacher attitudes in England and Norway. International Journal of Inclusive Education, 17(2), 192-204. http://dx.doi.org/10.1080/13603116.2011.629689

Lindle, J., \& Boyd, L. W. (1991). Parents, professionalism, and partnership in school-community relations. International Journal of Educational Research, 15, 323-337. http://dx.doi.org/10.1016/0883-0355(91)90008-G

Maital, S. L., \& Bornstein, M. H. (2003). The ecology of collaborative child rearing: A systems approach to child care on the Kibbutz. Ethos, 31(2), 274-306. http://dx.doi.org/10.1525/eth.2003.31.2.274

Market Response (2010). De rol van de omgeving bij de opvoeding: Onderzoek ten behoeve van het Opvoeddebat [The role of the environment in childrearing: A study for the purpose of the 'Childrearing debate']. Leusden, the Netherlands: Market Response.

Marshall, N. L., Noonan, A. E., McCartney, K., Marx, F., \& Keefe, N. (2001). It takes an urban village: Parenting networks of urban families. Journal of Family Issues, 22(2), 163-182. http://dx.doi.org/10.1177/019251301022002003

Mason, J., May, V., \& Clarke, L. (2007). Ambivalence and the paradoxes of grandparenting. The Sociological Review, 55(4), 687-706. http://dx.doi.org/10.1111/j.1467 -954X.2007.00748.x

McCartney, K., \& Phillips, D. (1988). Motherhood and childcare. In B. Birns \& D. Hay (Eds.), The different faces of motherhood (p. 157-183). New York, NY: Plenum press. http://dx.doi.org/10.1007/978-1-4899-2109-3_8

McGovern, M., \& Barry, M. M. (2000). Death education: Knowledge, attitudes, and perspectives of Irish parents and teachers. Death Studies, 24, 325-333. http://dx.doi.org/10.1080/074811800200487

Obeng, C. S. (2007). Immigrant families and childcare preferences: Do immigrants' cultures influence their childcare decisions? Early Childhood Education, 34(4), 259-264. http://dx.doi.org/10.1007/s10643-006-0132-9 


\section{Mll Macrothink}

Issues in Social Science

ISSN 2329-521X

2016, Vol. 4, No. 1

Petticrew, M., \& Roberts, H. (2006). Systematic reviews in the social sciences: A practical guide. Oxford, U.K.: Blackwell Publishing Ltd.

Raad voor Maatschappelijke Ontwikkeling [Dutch Council for Social Development] (2008). Versterken van de village. Preadvies over gezinnen en hun sociale omgeving [Strengthening the village. Preliminary report about families and their social environment]. In Versterking voor gezinnen [Strengthening families] (pp. 7-28). Den Haag, the Netherlands: RMO/ RVZ.

Raad voor Maatschappelijke Ontwikkeling [Dutch Council for Social Development] (2009). Investeren rondom kinderen [Investing in children]. Den Haag, the Netherlands: RMO/ RVZ.

Raad voor Maatschappelijke Ontwikkeling [Dutch Council for Social Development] (2012). Ontzorgen en normaliseren. Naar een sterke eerstelijns jeugd-en gezinscoach. [Unburden and normalize. Toward a strong first-line youth and family coach]. Den Haag, the Netherlands: RMO.

Rhodes, J. E., Ebert, L., \& Fischer, K. (1992). Natural mentors: An overlooked resource in the social networks of young African American mothers. American Journal of Community Psychology, 20(4), 445-461. http://dx.doi.org/10.1007/BF00937754

Sampson, R. J., Morenoff, J. D., \& Earls, F. (1999). Beyond social capital: Spatial dynamics of collective efficacy for children. American Sociological Review, 64, 633-660. http://dx.doi.org/10.2307/2657367

Scales, P. C., \& Gibbons, J. L. (1996). Extended family members and unrelated adults in the lives of young adolescents: A Research Agenda. Journal of Early Adolescence, 16, 365-390. http://dx.doi.org/10.1177/0272431696016004001

Scales, P. C., Benson, P. L., Roehlkepartain, E. C., Hintz, N. R., Sullivan, T. K., \& Mannes, M. (2001). The role of neighborhood and community in building developmental assets for children and youth: A national study of social norms among American adults. Journal of Community Psychology, 29(6), 703-727. http://dx.doi.org/10.1002/jcop.1044

Scales, P. C. (2003). Other people's kids: Social expectations and American adults' involvement with children and adolescents. New York, NY: Kluwer Academic/ Plenum Publishers.

Scales, P. C., Benson, P. L., Roehlkepartain, E. C., Hintz, N. R., Sullivan, T. K., \& Mannes, M. (2004). The role of parental status and child age in the engagement of children and youth with adults outside their families. Journal of Family Issues, 25(4), I735-760. http://dx.doi.org/10.1177/0192513X03259139

Singer, E. (1992). Ouders over leidsters in kinderdagverblijven [Parents about child care workers in childcare centers]. Kind en Adolescent, 13, 1-9.

Sormunen, M., Tossavainen, K., \& Turunen, H. (2012). Parental perceptions of the roles of home and school in health education for elementary school children in Finland. Health Promotion International, 28(2), 244-256. http://dx.doi.org/10.1093/heapro/das004 


\section{Macrothink}

Spencer, R., Basualdo-Delmonico, A., \& Lewis, T. O. (2011). Working to make it work: The role of parents in the youth mentoring process. Journal of community Psychology, 39(1), 51-59. http://dx.doi.org/10.1002/jcop.20416

Sterrett, E. M., Jones, D. J., McKee, L. G., \& Kincaid, C. (2011). Supportive non-parental adults and adolescent psychosocial functioning: Using social support as a theoretical framework. American Journal of Community Psychology, 48(3-4), 284-295. http://dx.doi.org/10.1007/s10464-011-9429-y

Uttal, L. (1996). Custodial care, surrogate care, and coordinated care: Employed mothers and the meaning of child care. Gender and Society, 10(3), 291-311. http://dx.doi.org/10.1177/089124396010003006

Van Daalen, R. (2010). Children and childhood in Dutch society and Dutch sociology. Current Sociology, 58(2), 351-368. http://dx.doi.org/10.1177/0011392109354249

Verzaro-Lawrence, M. (1981). Shared childrearing: A challenging alternative lifestyle. Alternative Lifestyles, 4(2), 205-217. http://dx.doi.org/10.1007/BF01082335

Weaver, A. D., Byers, E. S., Sears, H. A., Cohen, J. N., \& Randall, H. E. S. (2002). Sexual health education at school and at home: Attitudes and experiences of New Brunswick parents. The Canadian Journal of Human Sexuality, 11(1), 19-31.

Werner, E. E. (1993). Risk, resilience, and recovery: Perspectives from the Kauai longitudinal study. Development and Psychopathology, 5, 503-515. http://dx.doi.org /10.1017/S095457940000612X

Wyman, J., Price, J. H., Jordan, T. R., Dake, J. A., \& Telljohann, S. K. (2006). Parents' perceptions of the role of schools in tobacco use prevention and cessation for youth. Journal of Community Health, 31(3), 225-24. http://dx.doi.org/10.1007/s10900-005-9010-4 


\section{Appendix I}

Table 1. Summary of the characteristics of the publications included in the study $(N=49$, in alphabetical order).

\begin{tabular}{|c|c|c|c|c|}
\hline Reference & Content area & Publication type & Sample & Main conclusions \\
\hline Åman-Back et al. (2007) & $\begin{array}{l}\text { School involvement in } \\
\text { non-academic childrearing }\end{array}$ & Questionnaires & $\begin{array}{l}1.107 \text { parents and } 123 \\
\text { teachers from Finland }\end{array}$ & $\begin{array}{l}\text { Respondents agreed they share responsibility } \\
\text { for teaching a variety of non-academic skills }\end{array}$ \\
\hline Bakker et al. (2007) & $\begin{array}{l}\text { School involvement in } \\
\text { non-academic childrearing }\end{array}$ & Book chapter & - & $\begin{array}{l}\text { Current education policy creates barriers that } \\
\text { hold teachers back from non-academic topics }\end{array}$ \\
\hline Benson (2006) & $\begin{array}{l}\text { Approach for community } \\
\text { involvement in childrearing }\end{array}$ & Book & - & $\begin{array}{l}\text { Author makes recommendations for shift } \\
\text { toward an "all kids are our kids" norm }\end{array}$ \\
\hline Berne et al. (2000) & $\begin{array}{l}\text { School involvement in } \\
\text { sexual health education }\end{array}$ & Focus groups (FG) & $\begin{array}{l}19 \mathrm{FG} \text { with } 6-12 \text { parents of secondary } \\
\text { students in Australia (exact } N \text { unknown) }\end{array}$ & $\begin{array}{l}\text { Parents appreciate teachers' involvement, it } \\
\text { makes sexual education at home easier }\end{array}$ \\
\hline Bould (2003) & $\begin{array}{l}\text { Characteristics of caring } \\
\text { neighborhoods }\end{array}$ & Interviews & $\begin{array}{l}141 \text { parents from } 47 \text { U.S. neighborhoods ( } 3 \text { per } \\
\text { neighborhood, living in different households) }\end{array}$ & $\begin{array}{l}\text { Caring neighborhoods have specific } \\
\text { characteristics, e.g., privacy is little valued }\end{array}$ \\
\hline Bowden T. et al. (2008) & $\begin{array}{l}\text { Childrearing in a specific } \\
\text { region (Appalachia) }\end{array}$ & Interviews & $\begin{array}{l}46 \text { adolescents, parents and NPAs living } \\
\text { in the Appalachia (U.S. region) }\end{array}$ & $\begin{array}{l}\text { Community characteristics may influence } \\
\text { beliefs \& practices on collective childrearing }\end{array}$ \\
\hline Brayfield et al. (2011) & $\begin{array}{l}\text { Childrearing role of } \\
\text { childcare workers }\end{array}$ & Questionnaires & $\begin{array}{l}494 \text { Hungarian parents; } 89 \% \text { mothers, rest } \\
\text { mainly fathers, few grandmothers \& guardians }\end{array}$ & $\begin{array}{l}\text { Respondents see roles of childcare workers as } \\
\text { "different, but complementary" (p. 277) }\end{array}$ \\
\hline Budini Gattai et al. (1999) & $\begin{array}{l}\text { Childrearing role of } \\
\text { grandmothers }\end{array}$ & Interviews & 30 Italian grandmothers & $\begin{array}{l}\text { Grandparental involvement is valuable for } \\
\text { all parties, but surrounded with sensitivities }\end{array}$ \\
\hline Burchinal et al. (2008) & $\begin{array}{l}\text { Neighborhood characteristics } \\
\text { and types of childcare }\end{array}$ & Questionnaires & $\begin{array}{l}1121 \text { ethnically diverse U.S. mothers of } \\
\text { toddlers and/or preschoolers }\end{array}$ & $\begin{array}{l}\text { Neighborhood collective efficacy is related to } \\
\text { day center care and childcare by nonrelatives }\end{array}$ \\
\hline Chamberlain et al. (2003) & $\begin{array}{l}\text { Childrearing role of extended } \\
\text { family members }\end{array}$ & Case study & $\begin{array}{l}\text { Two case studies drawn from sample of } 60 \\
\text { three-generation Caribbean families in the U.K. }\end{array}$ & $\begin{array}{l}\text { Grandparental support reflects cultural beliefs } \\
\text { rather than economic necessity }\end{array}$ \\
\hline Cheatham et al. (2011) & $\begin{array}{l}\text { Expert roles of parents } \\
\text { and teachers }\end{array}$ & Interviews & $\begin{array}{l}8 \text { U.S. parents of child aged } 4-5 \text { years } \\
\text { considered at-risk and } 2 \text { teachers }\end{array}$ & $\begin{array}{l}\text { Teachers take expert role in parent-teacher } \\
\text { conferences, parents' expertise unrecognized }\end{array}$ \\
\hline Donner (1999) & $\begin{array}{l}\text { Childrearing in a specific } \\
\text { region (Polynesian society) }\end{array}$ & Ethnographic study & $\begin{array}{l}\text { Unknown amount of participant } \\
\text { observation and interviews }\end{array}$ & $\begin{array}{l}\text { Western policy may be partly responsible for } \\
\text { maintaining an ideology of sole responsibility }\end{array}$ \\
\hline
\end{tabular}




\begin{tabular}{|c|c|c|c|c|}
\hline Reference & Content area & Publication type & Sample & Main conclusions \\
\hline Dyson et al. (2012) & $\begin{array}{l}\text { School involvement in } \\
\text { sexual health education }\end{array}$ & Focus groups $(\mathrm{FG})$ & $\begin{array}{l}31 \text { Australian parents in } 4 \mathrm{FG} \text {; } \\
\text { majority were Australian-born mothers }\end{array}$ & $\begin{array}{l}\text { Parents want to be informed about content } \\
\text { of curriculum and teachers' qualifications }\end{array}$ \\
\hline Edwards et al. (2004) & $\begin{array}{l}\text { Parental norms about sources } \\
\text { of parenting support }\end{array}$ & Questionnaires & $\begin{array}{l}1.112 \text { U.K. parents; majority were } \\
\text { working class mothers }\end{array}$ & $\begin{array}{l}\text { Family and friends are regarded as the } \\
\text { people to turn to for most types of support }\end{array}$ \\
\hline Feldman et al. (1986) & $\begin{array}{l}\text { Childrearing in a specific } \\
\text { region (kibbutzim) }\end{array}$ & Questionnaires & 88 Israeli town and kibbutz mothers & $\begin{array}{l}\text { Nurturer-teacher role division may be specific } \\
\text { to childrearing ideology of kibbutzim }\end{array}$ \\
\hline Forsberg (2007) & $\begin{array}{l}\text { Expert roles of parents } \\
\text { and teachers }\end{array}$ & Ethnographic study & $\begin{array}{l}\text { Interviews with } 8 \text { Swedish parent couples } \\
\& \text { document analysis }(N=32 \text { school letters })\end{array}$ & $\begin{array}{l}\text { Parents' and teachers' responsibilities are } \\
\text { "negotiated in terms of expertise" (p. 286) }\end{array}$ \\
\hline Fothergill (2013) & $\begin{array}{l}\text { Childrearing role of } \\
\text { childcare workers }\end{array}$ & Ethnographic study & $\begin{array}{l}\text { FG and interviews with } 35 \text { U.S. mothers, } \\
27 \text { childcare workers, and } 6 \text { administrators }\end{array}$ & $\begin{array}{l}\text { Mothers' attitude to childcare is influenced } \\
\text { by messages, feelings of quilt, care quality }\end{array}$ \\
\hline Gillies (2004) & $\begin{array}{l}\text { Families' childrearing } \\
\text { networks }\end{array}$ & Interviews & $\begin{array}{l}35 \text { U.K. parents from } 24 \text { working class and } \\
\text { middle class households }\end{array}$ & $\begin{array}{l}\text { Parents are (still) embedded in reciprocal } \\
\text { networks, providing mainly practical support }\end{array}$ \\
\hline Gordon et al. (2013) & $\begin{array}{l}\text { Black fathers' perspectives } \\
\text { on shared childrearing }\end{array}$ & Interviews & 7 black fathers living in the U.S. & $\begin{array}{l}\text { Black fathers endorse the proverb that } \\
\text { "it takes a village to raise a child" }\end{array}$ \\
\hline Hunter et al. (1998) & $\begin{array}{l}\text { Childcare in black and } \\
\text { white urban families }\end{array}$ & Interviews & $\begin{array}{l}757 \text { self-identified caregivers from urban } \\
\text { U.S. families; } 581 \text { black, } 176 \text { white }\end{array}$ & $\begin{array}{l}\text { Black families more often share care with } \\
\text { extended family, people outside household }\end{array}$ \\
\hline Johnson F. et al. (2013) & $\begin{array}{l}\text { Childrearing in a specific } \\
\text { region (Tanzania) }\end{array}$ & Focus groups (FG) & $\begin{array}{l}10 \mathrm{FG} \text { with Tanzanian parents \& grandparents } \\
\text { (6-12 participants per FG, exact } N \text { unknown) }\end{array}$ & $\begin{array}{l}\text { Boundaries between parental and communal } \\
\text { childrearing responsibilities seem fluid }\end{array}$ \\
\hline Jones et al. (2007) & $\begin{array}{l}\text { Childrearing in African } \\
\text { American single-mother families }\end{array}$ & Literature review & - & $\begin{array}{l}\text { Re-conceptualization of coparenting } \\
\text { is needed: inclusion of NPAs }\end{array}$ \\
\hline Kakinuma (1993) & $\begin{array}{l}\text { Childrearing attitudes of } \\
\text { Japanese and U.S. mothers }\end{array}$ & $\begin{array}{l}\text { Document analysis } \\
\text { (parenting magazines) }\end{array}$ & - & $\begin{array}{l}\text { Differences in parental attitudes may reflect } \\
\text { differences in childrearing traditions }\end{array}$ \\
\hline Kegler et al. (2005) & $\begin{array}{l}\text { Neighborhood characteristics } \\
\text { and youth assets }\end{array}$ & $\begin{array}{l}\text { Interviews } \\
\text { (paired interviews) }\end{array}$ & $\begin{array}{l}1350 \text { ethnically diverse adolescents and } \\
\text { parents from inner-city U.S. households }\end{array}$ & $\begin{array}{l}\text { Neighborhood safety and social control } \\
\text { are related to existence of NPA role models }\end{array}$ \\
\hline Kesselring et al. (2012) & $\begin{array}{l}\text { Parents' attitudes to shared } \\
\text { childrearing }\end{array}$ & Questionnaires & 1090 parents from 17 Dutch neighborhoods & $\begin{array}{l}\text { Parents are ambivalent about involving } \\
\text { others in childrearing }\end{array}$ \\
\hline
\end{tabular}




\begin{tabular}{|c|c|c|c|c|}
\hline Reference & Content area & Publication type & Sample & Main conclusions \\
\hline Konijn (2008) & $\begin{array}{l}\text { Childrearing role of } \\
\text { playground employees }\end{array}$ & Questionnaires & 35 Dutch playground employees & $\begin{array}{l}\text { Playground employees do not see explicit } \\
\text { childrearing role for themselves }\end{array}$ \\
\hline Kurrien et al. (2004) & $\begin{array}{l}\text { Coparenting in Asian } \\
\text { families }\end{array}$ & Interviews & $\begin{array}{l}45 \text { Hindu mothers living in India and } 5 \text { intact } \\
\text { Vietnamese families living in the U.S. }\end{array}$ & $\begin{array}{l}\text { Re-conceptualization of the concept of } \\
\text { coparenting is needed: inclusion of NPAs }\end{array}$ \\
\hline Kyriacou et al. (2013) & $\begin{array}{l}\text { Student teacher attitudes to } \\
\text { social pedagogical role of schools }\end{array}$ & Questionnaires & $\begin{array}{l}542 \text { student teachers from England } \\
\text { and Norway }\end{array}$ & $\begin{array}{l}\text { Current education policy creates barriers that } \\
\text { hold teachers back from non-academic topics }\end{array}$ \\
\hline Lindle et al. (1991) & $\begin{array}{l}\text { Teachers' role } \\
\text { in childrearing }\end{array}$ & Interviews & $\begin{array}{l}45 \text { U.S. parents (majority white mothers) } \\
\text { and } 12 \text { teachers }\end{array}$ & $\begin{array}{l}\text { Parents do not relinquish responsibility, but } \\
\text { are interested in teachers' support }\end{array}$ \\
\hline Maital et al. (2003) & $\begin{array}{l}\text { Childrearing in a specific } \\
\text { region (kibbutzim) }\end{array}$ & Descriptive study & - & $\begin{array}{l}\text { Role differentiation between mother and } \\
\text { metapelet: nurturer-teacher division }\end{array}$ \\
\hline Market Response (2010) & $\begin{array}{l}\text { (Non)parents' attitudes to } \\
\text { childrearing role of NPAs }\end{array}$ & Questionnaires & $\begin{array}{l}795 \text { Dutch adults; } 394 \text { parents and } \\
401 \text { nonparents }\end{array}$ & $\begin{array}{l}\text { NPAs' involvement is desirable, but } \\
\text { comes with conditions }\end{array}$ \\
\hline Marshall et al. (2001) & $\begin{array}{l}\text { Families' childrearing } \\
\text { networks }\end{array}$ & Interviews & $\begin{array}{l}206 \text { ethnically diverse U.S. children and } \\
\text { their mothers }\end{array}$ & $\begin{array}{l}\text { African, European, and Hispanic American } \\
\text { parents differ in their social support networks }\end{array}$ \\
\hline Mason et al. (2007) & $\begin{array}{l}\text { Grandparents' role } \\
\text { in childrearing }\end{array}$ & Interviews & 46 grandparents living in the U.K. & $\begin{array}{l}\text { Grandparents continually try to balance } \\
\text { "not interfering" and "being there" (p. 701) }\end{array}$ \\
\hline McCartney et al. (1988) & $\begin{array}{l}\text { Mothers' attitudes on } \\
\text { childcare }\end{array}$ & Book chapter & - & $\begin{array}{l}\text { Western childrearing ideology may" reflect } \\
\text { and in turn promote" current values (p. 158) }\end{array}$ \\
\hline McGovern et al. (2000) & $\begin{array}{l}\text { School involvement in } \\
\text { discussing death and grief }\end{array}$ & Questionnaires & $\begin{array}{l}119 \text { Irish parents and } 142 \text { teachers } \\
\text { of primary school children }\end{array}$ & $\begin{array}{l}\text { Parents are positive about school programs } \\
\text { discussing death and grief }\end{array}$ \\
\hline Obeng (2007) & $\begin{array}{l}\text { Immigrant families' child } \\
\text { care preferences }\end{array}$ & Interviews & $\begin{array}{l}18 \text { African immigrant parents } \\
\text { living in the U.S. }\end{array}$ & $\begin{array}{l}\text { Daycare is a form of childcare that matches } \\
\text { immigrants' culture of shared childrearing }\end{array}$ \\
\hline RMO (2008) & $\begin{array}{l}\text { Families' childrearing } \\
\text { networks }\end{array}$ & Report & - & $\begin{array}{l}\text { Families are less socially embedded due to } \\
\text { societal and policy influences }\end{array}$ \\
\hline RMO (2009) & $\begin{array}{l}\text { Families' childrearing } \\
\text { networks }\end{array}$ & Report & - & $\begin{array}{l}\text { Families are less socially embedded due to } \\
\text { societal and policy influences }\end{array}$ \\
\hline Scales et al. (2001) & $\begin{array}{l}\text { (Non)parents' attitudes to } \\
\text { childrearing role of NPAs }\end{array}$ & Interviews & $\begin{array}{l}1425 \text { ethnically diverse U.S. parents } \\
\text { and nonparents }\end{array}$ & $\begin{array}{l}\text { Dominance of nuclear family ideology } \\
\text { constrains sharing of responsibility in West }\end{array}$ \\
\hline
\end{tabular}




\begin{tabular}{|c|c|c|c|c|}
\hline Reference & Content area & Publication type & Sample & Main conclusions \\
\hline Scales et al. (2003) & $\begin{array}{l}\text { (Non)parents' attitudes to } \\
\text { childrearing role of NPAs }\end{array}$ & Book & Same sample as Scales et al. 2001 & $\begin{array}{l}\text { Dominance of nuclear family ideology } \\
\text { constrains sharing of responsibility in West }\end{array}$ \\
\hline Scales et al. (2004) & $\begin{array}{l}\text { (Non)parents' attitudes to } \\
\text { childrearing role of NPAs }\end{array}$ & Interviews & Same sample as Scales et al. 2001 & $\begin{array}{l}\text { Dominance of nuclear family ideology } \\
\text { constrains sharing of responsibility in West }\end{array}$ \\
\hline Singer (1991) & $\begin{array}{l}\text { Childrearing role of } \\
\text { childcare workers }\end{array}$ & Interviews & $\begin{array}{l}144 \text { Dutch parents; } 101 \text { mothers, } 43 \text { fathers, } \\
\text { majority were highly educated }\end{array}$ & $\begin{array}{l}\text { Parents only delegate some of their } \\
\text { responsibilities to childcare workers }\end{array}$ \\
\hline Sormunen et al. (2012) & $\begin{array}{l}\text { School involvement in } \\
\text { health education }\end{array}$ & Questionnaires & $\begin{array}{l}184 \text { Finnish parents of } 10-11 \text { year old } \\
\text { children }\end{array}$ & $\begin{array}{l}\text { Parents see some topics as solely their } \\
\text { responsibility, others as joint responsibility }\end{array}$ \\
\hline Spencer et al. (2011) & $\begin{array}{l}\text { Childrearing role of } \\
\text { mentors }\end{array}$ & Interviews & $\begin{array}{l}13 \text { ethnically diverse U.S. parents of child } \\
\text { participating in mentoring program }\end{array}$ & $\begin{array}{l}\text { Parents believe mentors fulfill an additional } \\
\text { role, e.g., role model, confidant }\end{array}$ \\
\hline Uttal (1996) & $\begin{array}{l}\text { Employed mothers' } \\
\text { attitudes on childcare }\end{array}$ & Interviews & $\begin{array}{l}31 \text { ethnically diverse employed U.S. mothers } \\
\text { of preschoolers, toddlers or infants }\end{array}$ & $\begin{array}{l}\text { Mothers report sharing responsibility but set } \\
\text { conditions, e.g., childcare philosophy }\end{array}$ \\
\hline Van Daalen (2010) & $\begin{array}{l}\text { Historical overview of } \\
\text { childrearing in the Netherlands }\end{array}$ & Descriptive study & - & $\begin{array}{l}\text { Strong cultural ideal may have hindered } \\
\text { partial transfer of responsibilities to NPAs }\end{array}$ \\
\hline Verzaro-Lawrence (1981) & $\begin{array}{l}\text { Mothers' attitudes to } \\
\text { childcare }\end{array}$ & Descriptive study & - & $\begin{array}{l}\text { There appear to be several stressors in the } \\
\text { mother-childcare worker relationship }\end{array}$ \\
\hline Weaver et al. (2002) & $\begin{array}{l}\text { School involvement in } \\
\text { sexual health education }\end{array}$ & Questionnaires & 4206 Canadian parents; $89 \%$ mothers & $\begin{array}{l}\text { Parents want to be involved/informed and } \\
\text { provided with communication strategies }\end{array}$ \\
\hline Wyman et al. (2006) & $\begin{array}{l}\text { School involvement in } \\
\text { smoking prevention }\end{array}$ & Questionnaires & 456 U.S. parents; $51 \%$ fathers, $94 \%$ white & $\begin{array}{l}\text { Parents appreciate schools' involvement, } \\
\text { but want to be involved and informed }\end{array}$ \\
\hline
\end{tabular}

